\title{
Epigenetic Modifications in Lymphoma and Their Role in the Classification of Lymphomas
}

\author{
Sean Harrop ${ }^{1, *}$, Costas Kleanthes Yannakou ${ }^{2}$, Carrie Van Der Weyden ${ }^{1}$ and Henry Miles Prince ${ }^{1,2,3}$ (ID) \\ 1 Peter MacCallum Cancer Center, Melbourne, VIC 3000, Australia; \\ carrie.vanderweyden@petermac.org (C.V.D.W.); miles.prince@petermac.org (H.M.P.) \\ 2 Epworth HealthCare, East Melbourne, VIC 3002, Australia; costas.yannakou@epworth.org.au \\ 3 Sir Peter MacCallum Department of Oncology, University of Melbourne, Parkville, VIC 3052, Australia \\ * Correspondence: sean.harrop@petermac.org
}

check for

updates

Citation: Harrop, S.; Yannakou, C.K.; Van Der Weyden, C.; Prince, H.M.

Epigenetic Modifications in

Lymphoma and Their Role in the

Classification of Lymphomas. Hemato

2022, 3, 174-187. https://doi.org/

10.3390/hemato3010015

Academic Editor: Jude Fitzgibbon

Received: 26 January 2022

Accepted: 16 February 2022

Published: 21 February 2022

Publisher's Note: MDPI stays neutral with regard to jurisdictional claims in published maps and institutional affiliations.

Copyright: (C) 2022 by the authors. Licensee MDPI, Basel, Switzerland. This article is an open access article distributed under the terms and conditions of the Creative Commons Attribution (CC BY) license (https:// creativecommons.org/licenses/by/ $4.0 /)$.

\begin{abstract}
The characterisation of the lymphoma epigenome has provided insight into mechanisms involved in lymphomagenesis. Multiple lymphoma subtypes demonstrate recurrent mutations in key epigenetic regulators that have been utilised to define clinicogenetic groups that can predict clinical behaviour in these heterogenous entities. The high frequency of mutations in epigenetic regulators provides rationale to incorporate these in the classification of some subtypes of lymphoma. In addition, their recurrent nature provides a rationale to target such mutations, or the relevant pathway, for treatment. In this review, we summarised the available literature on epigenetic dysregulation in lymphoma and how it has been utilised in diagnosis and classification.
\end{abstract}

Keywords: lymphomagenesis; methylation; histone modification

\section{Introduction}

Epigenetics describes the modification of the transcription of genetic code independent of the DNA sequence. This is usually via the regulation of DNA methylation and histone modification, which controls gene expression and plays a critical role in normal cellular differentiation and growth. The epigenome is important for normal lymphocyte development and plays a role in the normal immune response [1]. Beyond normal development, the deregulation of the epigenome is frequently observed in human cancers and is thought to play a key role in oncogenesis through the silencing of tumour suppressor genes, as well as through changes in the tumor microenvironment (TME) and immune response [2].

With respect to lymphoma, epigenetic alterations are frequently observed across many subtypes. Indeed, the development of rapid and accurate gene sequencing technologies, such as next generation sequencing (NGS), has led to the use of mutational profiling as an integral component of lymphoma classification; mutations of epigenetic genes are frequently encountered. The detection of these epigenetic aberrancies may be useful diagnostically, as certain mutational profiles are supportive of a particular diagnosis. This is particularly relevant in the T-cell lymphomas, such as angioimmunoblastic T-cell lymphoma (AITL), where histological diagnosis can be challenging.

There is an emerging recognition that patterns of epigenetic dysregulation, which are often reflective of the underlying stage of differentiation, can be prognostically relevant; specific epigenetic mutations have now been incorporated into prognostic scores [3]. Certain lymphoma subtypes, such as follicular lymphoma (FL), have a significant degree of epigenetic dysregulation, which likely drives lymphomagenesis and disease progression. These mutations have proven to be therapeutically exploitable [4].

In this review, we highlight the progress that has been made in characterising the epigenetic landscape of different subtypes of lymphoma, with a particular focus on how epigenetic dysregulation contributes to the evolving classification of lymphoma. 


\section{Key Epigenetic Regulators Involved in Lymphomagenesis}

Epigenetic dysregulation occurs through a complex interplay of different mechanisms, including somatic mutations in key proteins involved in DNA methylation and histone acetylation, deacetylation, and methylation. These alterations influence gene transcription, leading to either the activation or repression of key tumour suppressor genes, DNA repair proteins and cell cycle regulators. Some of the most frequent, recurrently mutated key regulators in lymphoma are described below.

$E Z H 2$ : The Enhancer of zeste homolog 2 (EZH2) encodes the catalytic subunit of the polycomb repressive complex 2 that mediates histone methylation, leading to transcriptional silencing. Expression of mutant $E Z H 2$ impairs germinal center differentiation, driving aberrant proliferation by silencing genes such as IRF4 and PRDM1 [5]. Tumours that lack MHCI and MHCII are enriched for EZH2 mutations, supporting the role of epigenetic regulation in immune evasion [6]. $\mathrm{EZH} 2$ was one of the first recurrently mutated epigenetic regulators identified in FL and has provided a novel therapeutic target [7].

KMT2: The histone lysine methyltransferase 2 (KMT2) proteins, previously known as mixed lineage leukaemia $(M L L)$, form complexes that methylate lysine 4 on histone H3 (H3K4). Mutations in KMT2 are seen across all types of human cancers; they are the most frequently detected mutations in FL, where they have a tumour suppressor function by impeding B-cell differentiation [8].

CREBBP: CREB binding protein (CREBBP) has histone acetyltransferase activity and is structurally and functionally similar to EP300. Loss-of-function mutations in CREBBP have been demonstrated to cooperate with $B C L 2$ and to lead to a reduction in histone acetylation affecting germinal center development and B-cell signalling pathways $[9,10]$. In vitro disruption of $C R E B B P$ has been demonstrated to promote lymphomagenesis via accelerated cellular growth and MHCII downregulation, providing evidence of the tumour suppressor role that these pathways play in addition to altering the TME to favour malignant proliferation [9].

ARID1A: AT-rich interactive domain-containing protein 1A (ARID1A) promotes the formation of SWI/SNF nucleosome remodelling complexes containing BRG1 or BRM, which catalyse disruption of DNA-histone contacts, thereby, controlling chromatin condensation and DNA accessibility. ARID1A is critical for maintaining haematopoiesis, with differentiation of both myeloid and lymphoid lineages impaired in ARID1A knockout mice [11].

DNMT3A: DNA methyltransferase 3A (DNMT3A) functions as a DNA methyltransferase catalysing cytosine methylation of $\mathrm{CpG}$ islands in promoters, leading to transcriptional silencing. DNMT3A is critical for hematopoietic stem cell differentiation; mutations in this gene are thought to be early events in lymphoid malignancies [12].

TET2: The ten eleven translocation 2 (TET2) gene encodes an alpha-ketoglutarate dependent dioxygenase that regulates DNA hydroxymethylation by converting 5 -methylcytosine $(5 \mathrm{mC})$ to 5 -hydroxymethylcytosine $(5 \mathrm{hmC})$, which promotes DNA methylation. The interaction between mutated DNMT3A and TET2, which leads to a reduction and increase in global DNA methylation, respectively, creates a complex methylation landscape [13].

$I D H 2$ : Isocitrate dehydrogenase 2 (IDH2) converts isocitrate to a-ketoglutarate, a key co-factor in the oxidative demethylase reactions that remove methyl-groups from DNA. Mutant IDH2 converts isocitrate to 2-hydroxyglutarate, which is an oncogenic metabolite that cannot function as an obligatory cofactor of TET catalytic functions. Mutations in IDH2 and TET2 reduce $5 \mathrm{hmC}$ levels due to global hypermethylation of promoters and $\mathrm{CpG}$, islands resulting in transcriptional repression [14].

\section{The B-Cell Lymphomas}

The B-cell lymphomas are genetically heterogenous malignancies derived from mature B-lymphocytes and characterised by a broad range of clinical features. The genetic processes that lead to lymphomagenesis include large chromosomal changes, classically chromosomal 
translocations involving the immunoglobulin heavy chain locus, copy number aberrancies and somatic mutations in key regulators of intracellular pathways. These genetic events result in hyperproliferative and anti-apoptotic activity and are recognised as key to the development of malignancy. Chromosomal translocations, while often entity defining, are, alone, mostly insufficient to lead to lymphomagenesis and are seen in the lymphocytes of healthy individuals. Age-related non-random genetic mosaicism has been associated with the development of lymphoid malignancy [15-17]. Epigenetic dysregulation leads to lymphomagenic alteration of gene expression required for germinal center development and post germinal center differentiation. FL and diffuse large B-cell lymphoma (DLBCL), in particular, are enriched for mutations of histone modifiers, while, in other subtypes, methylation profiles can be reflective of disease biology; epigenetic mutations have been shown to contribute to clinical behaviour.

\subsection{Follicular Lymphoma}

FL is a malignancy of germinal center B cells that share the cellular architecture of the normal lymphoid follicle. There is recognition that, beyond classical FL, there is a range of mature B-cell neoplasms with a follicular growth pattern, such as diffuse variant of FL and paediatric nodal FL, that differ in their clinical behaviour and genetic mutation repertoire. Conventional FL is defined by the hallmark $\mathrm{t}(14: 18)$ translocation that juxtaposes the IGH and $B C L 2$ loci, leading to anti-apoptotic activity. Despite this early and disease-defining event, there is an appreciation that additional genetic aberrancies that alter normal germinal cell differentiation and the tumour microenvironment are required for the development of lymphoma. This is supported by the identification of the translocation in healthy individuals' lymphocytes often years prior to diagnosis, where a high prevalence of $t(11: 14)$ predicts the eventual development of FL [18].

The accumulation of further molecular lesions in these lymphocytes is thought to be needed for progression to overt FL; there is an enrichment of epigenetic dysregulation that is seen in almost all cases of conventional FL $(>85 \%)$. NGS has identified frequent mutations in epigenetic regulators KMT2D (80\%), CREBBP (33-68\%), EZH2 (25\%), ARID1A $(14 \%)$, and EP300 (9\%), which result in gene repression via histone modification. Moreover, there is often the presence of multiple epimutations within a single tumour-at least $50 \%$ of cases have both KMT2D and CREBBP mutations. The implications of the resultant histone modifications for lymphomagenesis are yet to be fully understood but suggest a state of transcriptional repression $[6,14,15]$.

Epigenetic pathway alterations are thought to be an early clonal event. In-situ follicular neoplasia is a collection of clonal B-cells within a lymph node that carries the $B C L 2$ rearrangement and is recognised as a precursor state to FL. These early clonal lesions can harbour mutations in CREBBP and EZH2, while mutations in KMT2D are also seen but less commonly supporting increasing epigenetic complexity as a key driver of oncogenesis $[16,17]$. The cumulative result of this complex dysregulation is the promotion of differentiation block at the germinal center stage of development, the loss of key tumour suppressors and an alteration in the tumour microenvironment that promotes and sustains lymphomagenesis.

The clinicogenetic risk model M7-FLIPI combined mutations in seven key genes, including epigenetic regulators EZH2, ARID1A, CREBBP and EP300 with the follicular international prognostic index (FLIPI) and Eastern Cooperative Oncology Group (ECOG) performance status; it was validated in the GALLIUM cohort $[3,19]$. The model stratifies patients into "low-risk" and "high risk" cohorts by M7-FLIPI score. Mutations in EZH2 and ARID1A convey better outcomes, while CREBBP/EP300 are associated with a worse prognosis. In comparison to the conventional FLIPI score, the M7-FLIP is more accurate in predicting progression of disease within 24 months (POD24) and discriminating between low- and high-risk patients [20]. The predictive power of M7-FLIPI, however, may be limited to patients treated with chemotherapy-based regimens $[3,21]$. 
Somatic mutations in EZH2 have been demonstrated to have significantly longer progression free survival and less early relapse [22]. EZH2 is essential for normal GC differentiation; alterations have been demonstrated to alter the TME by reducing tumour dependence on T-follicular helper cells, allowing for the persistence of tumour cells in the germinal center. This change in the microenvironment is reflected in a reduction in the number of tumour-infiltrating lymphocytes in lymphomas with EZH2 mutation [6]. Single-amino acid changes at Y641 in the catalytic SET domain are the most frequently seen $E Z H 2$ mutations in FL and result in higher levels of trimethylation at H3K27 (H3K27Me3) on the histone tail. EZH2 mutations are of clinical interest, as they have proven to be therapeutically vulnerable $[4,7]$.

Primary cutaneous follicle center lymphomas (pcFCL) are indolent B-cell lymphomas that are distinct from secondary cutaneous involvement by systemic FL. They have similar histological features but tend to have weaker CD10 expression and are negative for BCL2 expression. Clinicopathologically, it can be difficult to differentiate pcFCL from skin restricted FL at diagnosis; however, comprehensive genomic assessment by whole exome sequencing (WES) and for copy number aberrancies has demonstrated that alterations in chromatin modifying genes are infrequent when compared to FL. Indeed, cases of 'pcFCL' with mutations in the chromatin modifiers were more likely to progress to systemic involvement and, perhaps, were biologically 'conventionalsystemic' FL. Zhou et al. proposed a criterion that incorporated the presence of mutations in chromatin modifying genes (EZH2, KMT2D, CREBBP, EP300) along with BCL2 gene rearrangement and a high proliferative index (Ki-67 > 30\%) for distinguishing between pcFCL and cutaneous involvement of FL [23].

Diffuse variant of FL (dFL) is a rare variant of FL that also lacks the $t(14: 18)$ translocation, has low-grade histology and a typically favourable prognosis. Mutations in CREBBP are seen in $>90 \%$ of cases and are frequently bi-allelic and co-exist with STAT6 mutations, suggestive of a level of cooperativity. The transcription factor STAT6 is frequently mutated in primary mediastinal B-cell lymphoma but not germinal center B-cell (GCB)-subtype DLCBL. The BCL2-like antiapoptotic protein BCL-xL/BCL2L1 is a key target of STAT6 [24-26]. Epigenetic mutations are typically lacking in another rare variant of $t(14 ; 18)$-negative $\mathrm{FL}$, paediatric type nodal FL, which has a very favourable prognosis and is characterised by recurrent mutations in $M A P K$ pathway signalling [27].

\subsection{Diffuse Large B-Cell Lymphoma}

DLBCL has remarkable genetic heterogeneity. Gene expression profiling (GEP) via DNA microarray has been utilised to identify molecular subtypes of DLCBL, leading to the 'cell of origin (COO)' classification, which broadly divides DLBCL into GCB and activated B-cell (ABC) type, leaving 10\% unclassifiable [28]. Despite this broad division, DLBCL tumours have one of the highest tumour mutational burdens (TMB) of any malignancy, with somatic mutations recognized in over 700 genes [29]. The GCB subtype has similar genetic lesions to $\mathrm{FL}$, with frequent expression of $E Z H 2$, while the $\mathrm{ABC}$ subtype is enriched with mutations of B-cell receptor signalling pathways [30].

There are various immunohistochemistry-based algorithms that approximate the GEP-derived cell-of-origin classification. The most widely used is the Hans algorithm, which can be used to divide DLCBL into GCB and non-GCB, mostly ABC subtype, and which has a high concordance with GEP (80\%) [31]. The Hans algorithm uses expression of CD10, BCL6 and MUM1 to assign the subtype, while newer algorithms utilize further immunostains to improve accuracy. Expression of these immunostains appears to be independent of epigenetic aberrancies. Indeed, expression of EZH2 appears to not be restricted to COO subtype, with high levels seen regardless of EZH2 mutation status [32,33]. These algorithms are imperfect classifications with substantial heterogeneity within each group. In part, this may be because the $\mathrm{COO}$ classification provides a phenotypic description of the lymphoma cell and does not necessarily fully reflect the complex, dysregulated biological pathways involved. 
Genome-wide methylation studies have demonstrated that, as in many other cancers, disrupted methylation is frequent in DLCBL and higher levels of aberrant DNA methylation are associated with a poorer prognosis [34]. Epigenetic dysregulation provides a permissive transcriptional environment that promotes germinal center development, while silencing tumour suppressors and suppressing terminal differentiation. A pivotal paper by Morin et al. reported frequent mutations in epigenetic regulatory genes in $32 \%$ of patients with DLBCL with enrichment of these alterations seen in the GCB subtype [7]. A similar mutational profile, including sequence variants of EZH2, CREBBP and EP300, among others, was seen across patients with FL (89\% of patients) analysed in the same study, highlighting the genetic similarity between FL and the GCB subtype of DLCBL, where epigenetic disruption appears to play a key role in the lymphomagenesis in both entities [7,35].

As mentioned, DLBCL has been associated with many somatic mutations [29]. Clustering of recurrent somatic mutations within subtypes was reported by Schmitz et al., who utilised WES, targeted sequencing, and copy number analysis to characterise the genomic landscape of DLBCL [36]. An algorithm used key mutations to converge on four clinicogenetic subtypes MCD (MYD88/CD79B), BN2 (BCL6/NOTCH2), N1 (NOTCH1), and EZB (EZH2/BCL2) (Table 1). The MCD and N1 subtypes overlapped genetically with ABC subtype, while the EZB subtype shared the genetic hallmarks of GCB. Genetic alterations in epigenetic regulatory genes were seen across the GCB-ABC 'spectrum' but were enriched in the GCB subtype. EZH2 mutations were almost exclusive to the GCB-subtype, as were loss-of-function mutations in the tumour suppressor CREBBP, which cooperates with BCL2 overexpression to promote lymphomagenesis [10].

Epigenetic aberrancy was enriched in, but not exclusive to, the EZB subtype. SET domain containing 1B (SETD1B), also known as KMT2G and part of the KMT2 histone lysine methyltransferase family, was incorporated in the MCD subtype and was seen in $25 \%$ of ABC DLBCL. Mutations in SETD1B are also frequently seen in DLBCL subtypes in which ABC type predominates, such as primary CNS lymphoma and intravascular lymphoma, a rare extranodal lymphoma of small blood vessels with lymphadenopathy, where SETD1B mutants are seen in approximately $50 \%$ of cases $[37,38]$.

TET2 was the most frequently seen mutation in the "unclassifiable" subtype. TET2 somatic mutations occur recurrently in approximately $10 \%$ of DLBCL. Intact TET2 promotes DNA methylation via the oxidization of 5-methylcytosine to 5-hydroxymethylcytosine $(5 \mathrm{hmC})$ and is required for germinal center B cells to undergo plasma cell differentiation. TET2-deficient germinal center B cells cannot up-regulate the plasma cell master regulator PRDM1 due to reduction in $5 \mathrm{hmC}$ [39]. Genome-wide methylation profiling has demonstrated a distinct methylation profile in TET2 mutated DLBCL; however, there does not appear to be a clinically relevant difference in patients with TET2 mutant versus wild-type DLBCL [40].

Similar comprehensive genetic analysis was performed by Chapuy et al. who described five distinct genetic clusters (C1, C2, C3, C4 and C5). The C3 cluster, which is genetically similar to the previously described EZB subtype, had frequent mutations in KMT2D, CREBBP and EZH2 and had substantial genetic overlap with GCB. There was a particularly high incidence of $C R E B B P$ mutations $(53 \%)$. The $C 4$ cluster, which is also mostly GCB subtype and which has a distinctly favourable prognosis, lacked the chromatin modifier mutations seen in the C3 subtype; however, recurrent mutations in histone linker genes were seen [41].

Genetic clustering methodology was further refined with the LymphGen classification system, which divided DLBCL into six genetically defined subgroups (EZB, ST2, BN2, A53, N1, MCD) based on prevalent hallmark mutations [42]. The EZB subtype is, again, defined by epigenetic dysregulation, which is a defining attribute of EZB due to loss-of-function mutations of several epigenetic regulators (KMT2D, CREBBP, EP300, ARID1A) and gainof-function of EZH2. The ST2 subtype is characterized by recurrent loss-of-function TET2 mutations suggestive of tumour-suppressor function. 
Table 1. Corresponding Diffuse Large B-cell Lymphoma subtypes based on genetic mutations

* Epigenetic regulatory gene.

\begin{tabular}{|c|c|c|c|c|c|}
\hline $\begin{array}{c}\text { Genetic Subtype } \\
{[36]}\end{array}$ & $\begin{array}{c}\text { Genetic Cluster } \\
{[41]}\end{array}$ & $\begin{array}{c}\text { LymphGen } \\
\text { Classification [42] }\end{array}$ & Cell of Origin & $\begin{array}{l}\text { Characteristic } \\
\text { Mutations }\end{array}$ & 5-Year OS \\
\hline $\mathrm{BN} 2$ & Cluster 1 & $\mathrm{BN} 2$ & $\begin{array}{r}\text { ABC, GCB, } \\
\text { unclassified }\end{array}$ & $\begin{array}{c}\text { BCL6, NOTCH2, } \\
\text { TNFAIP3 }\end{array}$ & $36-79 \%$ \\
\hline- & Cluster 2 & A53 & $\mathrm{ABC}, \mathrm{GCB}$ & TP53 & $33-62 \%$ \\
\hline EZB & Cluster 3 & EZB & GCB & $\begin{array}{c}B C L 2, E Z H 2 * \\
C R E B B P *, K M T 2 D^{*}\end{array}$ & $48-68 \%$ \\
\hline- & Cluster 4 & ST2 & GCB & $\begin{array}{l}\text { TET2 *, SGK1, DUSP2, } \\
\text { ITPKB, NFKBIA }\end{array}$ & $72-84 \%$ \\
\hline MCD & Cluster 5 & MCD & $\mathrm{ABC}$ & $\begin{array}{c}\text { MYD88, CD79B, } \\
\text { CDKN2A, ETV6, SPIB }\end{array}$ & $26-54 \%$ \\
\hline N1 & - & N1 & $\mathrm{ABC}$ & NOTCH1, IRF2BP2 & $22-27 \%$ \\
\hline
\end{tabular}

Early attempts to utilise the burden of epigenetic mutations in DLBCL led to the development of the "EpiScore" by Szablewski et al. Utilizing GEP, they demonstrated that the level of expression of epigenetic regulators DNMT3A, DOT1L, and SETD8 was an independent predictor of survival with high levels of expression associated with a poorer prognosis [43]. Further work is needed, but the "EpiScore" or similar models may identify DLBCL patients, who may benefit from epigenetic-targeted therapies.

A molecular high-risk group of high-grade B-cell lymphoma (HGBCL) has been defined by Sha et al. using GEP [44]. This poor prognosis group with MYC and BCL2 and/or $B C L 6$ rearrangement (otherwise known as double-hit or triple-hit lymphomas) had recurrent mutations demonstrated via targeted sequencing in epigenetic genes such as EZH2 and KMT2D. Recurrent loss-of-function CREBBP mutations are also frequently (80\% of cases) seen in HGBCL [44,45]. The contribution of epigenetic dysregulation to the aggressive disease behaviour is unclear; however, epigenetic regulatory genes appear to be more frequently mutated in HGBCL than in GCB DLBCL.

These molecular classification schemas are yet to be recognised by the World Health Organization (WHO) classification of aggressive lymphomas, which still relies on the GEPdefined 'cell-of-origin' subtypes. The prognostic and potential therapeutic implications of mutation-defined subgroups within DLBCL, with the incorporation of high throughput sequencing, such as NGS, into routine clinical practice may change this. Frequent mutations in chromatin modifiers and other epigenetic regulators seen in certain mutation-defined subtypes may provide therapeutic rationale for harnessing therapies targeting epigenetic dysregulation as well as risk-adapted treatment strategies based on genomic classification.

\subsection{Mantle Cell Lymphoma}

Mantle cell lymphoma (MCL) is defined by $\mathrm{t}(11 ; 14)(\mathrm{q} 13 ; \mathrm{q} 32)$ leading to cyclin D1 overexpression and, generally, a poor overall survival rate and high rates of relapse.

High degrees of global epigenetic dysregulation are associated with more aggressive clinical behaviour. Genome wide methylation analyses have demonstrated heterogeneous patterns of DNA methylation in MCL with frequent hypermethylation of tumour suppressor genes, leading to transcriptional repression. A subset of MCL tumours have extensive CPG methylation that is associated with highly proliferative disease and a poorer prognosis [46,47].

There is a nodal variant that commonly involves the gastrointestinal tract and that requires early treatment, while the non-nodal leukemic variant usually demonstrates indolent clinical behaviour. SOX11 encodes for a transcription factor that is overexpressed in nodal MCL, with low levels seen in patients with the non-nodal leukemic variant. SOX11 
expression is under epigenetic control and may, in part, be responsible for the differing clinical phenotypes [46,48].

Loss of function mutations in the methyltransferase KMT2D appear to be relatively common, seen in $12-32 \%$ of cases, and may be associated with poorer outcome. NGS of a cohort of young MCL patients in the Fondazione Italiana Linfomi MCL0208 phase 3 trial (lenalidomide vs. observation post autologous transplantation) demonstrated loss of function of KMT2D in $13.4 \%$ of patients $(25 / 186)$, which was associated with a poorer 4-year progression-free-survival ( $33.2 \%$ vs. $63.7 \%)$ and overall survival $(62.3 \%$ vs. $86.8 \%$ ). The authors proposed the addition of KMT2D mutation to a prognostic index, the 'MIPI-genetic' score [49-51]. EZH2 expression may predict for a poorer prognosis in MCL. In a retrospective series of 166 patients, 57 patients (38\%) stained positive for EZH2 by immunohistochemistry. This finding was associated with a median overall survival of 4.6 years, compared to 9.6 years for those without EZH2 staining. EZH2 expression was also associated with aggressive histology and p53 overexpression ( $43 \%$ vs. $2 \%)[52]$.

\subsection{Chronic Lymphocytic Leukaemia/Small Lymphocytic Leukaemia}

A clinically heterogeneous disease, there are two distinct clinicobiologic subtypes of CLL based on the presence or absence of somatic mutations in the variable region of the immunoglobulin heavy-chain gene (IGHV). IGHV mutated CLL has a more favourable outcome and arises from the post-germinal center B cell, while IGHV unmutated CLL arises from the pre-germinal center B cell and typically has a poorer outcome.

The putative cell of origin is reflected in the epigenetic signature, with genome wide methylation studies revealing differences in the DNA methylation patterns of the two molecular subtypes [53]. Queirós et al. reported on the methylation status of five CpGs islands and identified three distinct groups, naive B-cell-like CLL (n-CLL), memory Bcell-like CLL (m-CLL) and intermediate CLL. The n-CLL and m-CLL group were closely associated with unmutated and mutated IGHV, respectively, and mirrored their biological behaviour. These epigenetic marks, representative of the cellular origin, were shown to be robust predictors of outcome [54]. Evolutions of methylation patterns have also been demonstrated during therapy, suggesting a dynamic epigenetic tumour response [55].

The chromatin modifier chromodomain helicase DNA binding protein 2 (CHD2) is one of the most recurrently mutated genes in IGHV mutated CLL (5\% of cases) and is thought to be a driver of malignancy [56]. However, the overall contribution of epigenetic dysregulation to CLL leukemogenesis is poorly defined.

\subsection{Marginal Zone Lymphoma}

Marginal zone lymphoma (MZL) is a relatively rare indolent lymphoma with three recognised subtypes, splenic MZL, extranodal MZL and nodal MZL. Recurrent mutations in epigenetic regulators, such as KMT2D and CREBBP, are seen across all subtypes [57-59]. Epigenetic dysregulation has been demonstrated to play a role in the clinical behaviour of splenic MZL, with higher degrees of promotor hypermethylation leading to inferior outcomes, possibly due to repression of key tumour suppressor genes such as KLF4 and CDKN2A [60].

\subsection{Classical Hodgkin's Lymphoma}

Classical Hodgkin's lymphoma (cHL) is derived from postgerminal center B cells and is usually composed of a small number of Hodgkin cells (multinucleated Reed-Sternberg cells) residing in an extensive inflammatory background. In contradistinction to other B-cell lymphomas, the malignant cells lack the expression of almost all B-cell markers, such as CD19, CD20 and CD79a. This downregulation has been demonstrated in vivo to be mediated, at least in part, by epigenetic silencing via hypermethylation of the promoter regions of these genes [61]. WES and NGS have demonstrated a heterogenous genetic landscape, with key signalling pathways, such as NF-kB and JAK/STAT, playing an important 
role. Frequent amplification of 9p24.1 is likely the basis for the response to PD-1/PD-L1 immune checkpoint inhibitors [62]. Recurrent mutations in epigenetic regulators, particularly CREBBP and EP300, have been demonstrated; however, the role that these play in lymphomagenesis and disease progression is unclear [63].

\section{The T-Cell Lymphomas}

T-cell lymphomas are rarer than their B-cell counterparts, comprising around $15 \%$ of all non-Hodgkin lymphomas. They are subdivided into the peripheral T-cell lymphomas (PTCL) and cutaneous T-cell lymphomas (CTCL). Although mutations in genes affecting chromatin structure and histone post-translational modification are frequent, as in B-cell lymphomas, the T-cell lymphomas are also enriched with sequence variants of genes that modulate DNA methylation, leading to a highly dysregulated epigenome in certain subtypes.

\subsection{Peripheral T-Cell Lymphoma-TFH Phenotype}

PTCL-NOS is the most common type of PTCL comprising around 25\% of new diagnoses. There is clinicogenetic heterogeneity and epigenetic mutations are less frequent than in other subtypes, such as angioimmunoblastic T-cell lymphoma (AITL). Previously classified under PTCL-NOS, peripheral T-cell lymphoma with T follicular helper phenotype (PTCL-TFH) was recognised by the WHO in 2016 as a distinct subtype and warrants special mention [64]. There is considerable overlap between PTCL-TFH and AITL with a shared $\mathrm{COO}$ and mutation profile. There is a recognition that these two entities may represent different ends of the spectrum of the same disorder, which is supported by their molecular characterisation. Frequent TET2 coding mutations in PTCL-TFH was demonstrated in an early series. The presence of TET2 mutations in this cohort was associated with advanced-stage disease and shorter PFS [65]. Subsequent targeted sequencing of PTCLTFH revealed mutations in genes frequently mutated in AITL, such as TET2, DNMT3A and RHOA G17V [66]. Furthermore, PTCL-TFH demonstrates responsiveness to therapy that targets the epigenome with retrospective data supporting the use of histone deacetylase inhibitors in this subtype [67].

\subsection{Angioimmunoblastic Lymphoma}

AITL is a prototypical epigenetic disorder characterised by a homogenous genetic landscape with hallmark mutations in TET2, IDH2 and RHOA leading to widespread aberrant DNA methylation. TET2 is the most commonly mutated gene in AITL and is reported in up to $80 \%$ of AITL while IDH2 mutations are identified in about a third of AITL cases [68]. The IDH2 R172 variant appears unique to AITL among lymphoma and generates 2HG, which can inhibit the TET2 enzyme. Given this, co-existent mutations would not be expected; however, most cases with IDH2 mutants also have TET2 mutation [69,70]. Mutations in TET2 and IDH2 are strongly associated with the RHOA G17V mutation, which is seen exclusively in the context of TET2 mutations with or without IDH2 mutations in $70 \%$ of AITL patients [71]. DNMT3 loss of function mutation is reported in 10-25\% of cases of AITL, of which $80 \%$ also have TET2 mutations. While these mutations in key epigenetic regulators contribute to the aberrant epigenome that leads to lymphomagenesis, it is not yet clear whether specific mutations alter prognosis. IDH2 mutations, for example, are commonly seen in acute myeloid leukaemia, where they are associated with a poorer prognosis. Despite this, they do not appear to be a prognostic biomarker in AITL [72]. This epigenetic dysregulation has been exploited therapeutically; therapies that target the epigenome have proven particularly beneficial in this disease entity [73].

\subsection{Mycosis Fungoides and Sezary Syndrome}

Mycosis fungoides (MF) is the most common CTCL variant and is related to the rare leukemic variant, Sézary syndrome (SS). Alterations in epigenetic regulators and cellular growth signalling pathways are frequent and oncogenic in these conditions. There is 
recurrent loss of function mutations in epigenetic regulators such as ARID1A (62\%) and DNMT3A (42\%) [74,75]. The degree of methylation aberrancy in CTCL is higher than many other malignancies, suggestive of the key role of the altered epigenome in pathogenesis [76]. CTCL tumour cells display widespread hypermethylation of CpG islands in promotor regions of tumour suppressor genes such as CDKN2A [77]. This hypermethylation involves the CMTM2 gene, which encodes a chemokine-like factor and appears to be distinct to SS. Furthermore, many of the highly expressed genes identified in SS, such as CD158, DNMT3 and PLS3, have large CpG islands, suggesting that changes in methylation may be a mechanism of hyper-expression [78]. Despite a highly dysregulated epigenome, it is currently unclear if clinically relevant subgroups can be delineated using methylation patterns or mutational profiling.

\section{Conclusions}

Dysregulation of the epigenome is a hallmark of human cancer and is frequent in lymphoid malignancies, where the epigenetic mechanisms that regulate lymphoid cell development are disrupted. Clearly, epigenetic changes that alter DNA transcription-whether that be through modification of function (i.e., hyperacetylation of histones) or through direct mutations of genes known to modify the epigenome-impact on the development and behaviour of various lymphoma types (Table 2). This review has focused on key genes that influence behaviour; there is no doubt that the detection of epigenetic alterations alters outcome, such that they are already being incorporated into prognostic algorithms, such as the M7-FLIPI for follicular lymphoma. Moreover, epigenetic mutations have already entered the WHO classification system for T cell lymphomas, defining the nodal PTCL with TFH phenotype. At this stage, it is probably too early to use epigenetic changes to re-define B cell lymphomas beyond the existing WHO classification that centers around the cell of origin concept, although EZB-DLBCL has to be a front-runner. Nonetheless, for all lymphomas, recognition of epigenetic changes is going to become increasingly important as we develop more complex prognostic tools.

Table 2. Utility of epigenetic dysregulation to classification and prognostication in lymphoma subtypes.

\begin{tabular}{|c|c|c|}
\hline Lymphoma Type & Epigenetic Dysregulation & Classification and Prognostic Utility \\
\hline Follicular Lymphoma & $\begin{array}{c}\text { Frequent mutations in regulators } \\
\text { including } K M T 2 D, C R E B B P, E Z H 2, \\
A R I D 1 A \text { and } E P 300\end{array}$ & $\begin{array}{c}E Z H 2, A R I D 1 A, C R E B B P \text { and } E P 300 \text { mutations } \\
\text { contribute to clinicogenetic risk model m7-FLIPI } \\
\text { EZH2 mutations identify prognostically favourable } \\
\text { subset of patients } \\
\text { Distinct epigenetic mutation clustering between FL } \\
\text { subtypes }\end{array}$ \\
\hline $\begin{array}{l}\text { Diffuse Large B-cell } \\
\text { Lymphoma }\end{array}$ & $\begin{array}{c}\text { Frequent mutations in regulatory genes } \\
\text { with enrichment seen in the GCB subtype. } \\
\text { A similar mutational profile to FL, with } \\
\text { sequence variants of } E Z H 2, C R E B B P \text { and } \\
E P 300\end{array}$ & $\begin{array}{l}\text { Clustering of mutations in epigenetic regulatory } \\
\text { genes define prognostically relevant subtypes of } \\
\text { DLBCL } \\
\text { Higher levels of aberrant DNA methylation are } \\
\text { associated with a poorer prognosis }\end{array}$ \\
\hline Marginal Zone Lymphoma & $\begin{array}{l}\text { Recurrent mutations in } K M T 2 D \text { and } \\
C R E B B P \text { are seen across all subtypes }\end{array}$ & $\begin{array}{l}\text { Higher degrees of promotor hypermethylation have } \\
\text { been demonstrated to lead to inferior outcomes }\end{array}$ \\
\hline Mantle Cell Lymphoma & $\begin{array}{l}\text { Frequent hypermethylation of tumour } \\
\text { suppressor genes leading to } \\
\text { transcriptional repression } \\
\text { Recurrent mutations in KMT2D }\end{array}$ & $\begin{array}{l}\text { Extensive CpG methylation associated a poorer } \\
\text { prognosis } \\
\text { Loss-of-function mutations in KMT2D may be } \\
\text { associated with poorer prognosis } \\
\text { Epigenetic regulation of } S O X 11 \text { expression }\end{array}$ \\
\hline $\begin{array}{l}\text { Classical Hodgkin's } \\
\text { Lymphoma }\end{array}$ & $\begin{array}{c}\text { Recurrent mutations in epigenetic } \\
\text { regulators seen, particularly } C R E B B P \text { and } \\
E P 300\end{array}$ & $\begin{array}{l}\text { Unclear role for epigenetic dysregulation in } \\
\text { prognosis or subclassification }\end{array}$ \\
\hline
\end{tabular}


Table 2. Cont.

\begin{tabular}{|c|c|c|}
\hline Lymphoma Type & Epigenetic Dysregulation & Classification and Prognostic Utility \\
\hline $\begin{array}{l}\text { Chronic Lymphocytic } \\
\text { Leukaemia }\end{array}$ & $\begin{array}{l}\text { Recurrent mutations in chromodomain } \\
\text { helicase DNA binding protein } 2 \text { (CHD2) }\end{array}$ & $\begin{array}{l}\text { Methylation status of CpGs islands identifies distinct } \\
\text { groups with differing prognosis }\end{array}$ \\
\hline $\begin{array}{c}\text { Peripheral T-cell lymphoma } \\
\text { TFH }\end{array}$ & $\begin{array}{l}\text { Frequent mutations in TET2, DNMT3A } \\
\text { and RHOA G17V }\end{array}$ & $\begin{array}{c}\text { Mutational profile of epigenetic regulators } \\
\text { distinguishes } \\
\text { this subtype from prior classification of PTCL-NOS } \\
\text { TET2 mutations may be associated with poor } \\
\text { prognosis }\end{array}$ \\
\hline $\begin{array}{l}\text { Angioimmunoblastic T-cell } \\
\text { Lymphoma }\end{array}$ & $\begin{array}{l}\text { Frequent hallmark mutations in TET2, } \\
\text { IDH2 and RHOA } \\
\text { Recurrent loss-of-function mutations in } \\
\text { DNMT3A }\end{array}$ & $\begin{array}{l}\text { Increasingly defined by presence of epigenetic } \\
\text { regulatory mutations } \\
\text { Unclear effect on prognosis of specific mutations }\end{array}$ \\
\hline $\begin{array}{l}\text { Mycosis Fungoides/Sezary } \\
\text { Syndrome }\end{array}$ & $\begin{array}{l}\text { Higher degree of methylation aberrancy } \\
\text { compared to other malignancies } \\
\text { Widespread hypermethylation of CpG } \\
\text { islands in promotor regions of tumour } \\
\text { suppressor genes such CDKN2A } \\
\text { Recurrent loss of function mutations in } \\
\text { ARID1A and DNMT3A. }\end{array}$ & $\begin{array}{l}\text { Unclear role for epigenetic dysregulation in } \\
\text { prognosis or subclassification despite high } \\
\text { dysregulated epigenome }\end{array}$ \\
\hline
\end{tabular}

Funding: This research received no external funding.

Informed Consent Statement: Not applicable.

Conflicts of Interest: The authors declare no conflict of interest.

\section{References}

1. Shaknovich, R.; Cerchietti, L.; Tsikitas, L.; Kormaksson, M.; De, S.; Figueroa, M.E.; Ballon, G.; Yang, S.N.; Weinhold, N.; Reimers, M.; et al. DNA methyltransferase 1 and DNA methylation patterning contribute to germinal center B-cell differentiation. Blood 2011, 118, 3559-3569. [CrossRef] [PubMed]

2. Marks, D.L.; Olson, R.L.; Fernandez-Zapico, M.E. Epigenetic control of the tumor microenvironment. Epigenomics 2016, 8 , 1671-1687. [CrossRef] [PubMed]

3. Pastore, A.; Jurinovic, V.; Kridel, R.; Hoster, E.; Staiger, A.M.; Szczepanowski, M.; Pott, C.; Kopp, N.; Murakami, M.; Horn, H.; et al. Integration of gene mutations in risk prognostication for patients receiving first-line immunochemotherapy for follicular lymphoma: A retrospective analysis of a prospective clinical trial and validation in a population-based registry. Lancet Oncol. 2015, 16, 1111-1122. [CrossRef]

4. Morschhauser, F.; Tilly, H.; Chaidos, A.; McKay, P.; Phillips, T.; Assouline, S.; Batlevi, C.L.; Campbell, P.; Ribrag, V.; Damaj, G.L.; et al. Tazemetostat for patients with relapsed or refractory follicular lymphoma: An open-label, single-arm, multicentre, phase 2 trial. Lancet Oncol. 2020, 21, 1433-1442. [CrossRef]

5. $\quad$ Béguelin, W.; Popovic, R.; Teater, M.; Jiang, Y.; Bunting, K.L.; Rosen, M.; Shen, H.; Yang, S.N.; Wang, L.; Ezponda, T.; et al. EZH2 is required for germinal center formation and somatic EZH2 mutations promote lymphoid transformation. Cancer Cell 2013, 23, 677-692. [CrossRef] [PubMed]

6. $\quad$ Ennishi, D.; Takata, K.; Béguelin, W.; Duns, G.; Mottok, A.; Farinha, P.; Bashashati, A.; Saberi, S.; Boyle, M.; Meissner, B.; et al. Molecular and Genetic Characterization of MHC Deficiency Identifies EZH2 as Therapeutic Target for Enhancing Immune Recognition. Cancer Discov. 2019, 9, 546. [CrossRef] [PubMed]

7. Morin, R.D.; Johnson, N.A.; Severson, T.M.; Mungall, A.J.; An, J.; Goya, R.; Paul, J.E.; Boyle, M.; Woolcock, B.W.; Kuchenbauer, F.; et al. Somatic mutations altering EZH2 (Tyr641) in follicular and diffuse large B-cell lymphomas of germinal-center origin. Nat. Genet. 2010, 42, 181-185. [CrossRef]

8. Zhang, J.; Dominguez-Sola, D.; Hussein, S.; Lee, J.-E.; Holmes, A.B.; Bansal, M.; Vlasevska, S.; Mo, T.; Tang, H.; Basso, K.; et al. Disruption of KMT2D perturbs germinal center B cell development and promotes lymphomagenesis. Nat. Med. 2015, 21, 1190-1198. [CrossRef]

9. Hashwah, H.; Schmid, C.A.; Kasser, S.; Bertram, K.; Stelling, A.; Manz, M.; Müller, A. Inactivation of CREBBP expands the germinal center B cell compartment, down-regulates MHCII expression and promotes DLBCL growth. Proc. Natl. Acad. Sci. USA 2017, 114, 9701. [CrossRef]

10. García-Ramírez, I.; Tadros, S.; González-Herrero, I.; Martín-Lorenzo, A.; Rodríguez-Hernández, G.; Moore, D.; Ruiz-Roca, L.; Blanco, O.; López, D.A.; Rivas, J.D.L.; et al. Crebbp loss cooperates with Bcl2 overexpression to promote lymphoma in mice. Blood 2017, 129, 2645-2656. [CrossRef] 
11. Han, L.; Madan, V.; Mayakonda, A.; Dakle, P.; Teoh, W.W.; Shyamsunder, P.; Nordin, H.B.M.; Cao, Z.; Sundaresan, J.; Lei, I.; et al. ARID1A Is Critical for Maintaining Normal Hematopoiesis in Mice. Blood 2018, 132 (Suppl. 1), 3833. [CrossRef]

12. Challen, G.A.; Sun, D.; Jeong, M.; Luo, M.; Jelinek, J.; Berg, J.S.; Bock, C.; Vasanthakumar, A.; Gu, H.; Xi, Y.; et al. Dnmt3a is essential for hematopoietic stem cell differentiation. Nat. Genet. 2011, 44, 23-31. [CrossRef] [PubMed]

13. Couronné, L.; Bastard, C.; Bernard, O.A. TET2 and DNMT3A mutations in human T-cell lymphoma. N. Engl. J. Med. 2012, 366, 95-96. [CrossRef] [PubMed]

14. François, L.; Elsa, P.; Aurélie, D.; Lucile, C.; Nadine, M.; Laurianne, S.; Fataccioli, V.; Bruneau, J.; Cairns, R.A.; Mak, T.W.; et al. Loss of 5-hydroxymethylcytosine is a frequent event in peripheral T-cell lymphomas. Haematologica 2018, 103, e115-e118.

15. Schüler, F.; Dölken, L.; Hirt, C.; Kiefer, T.; Berg, T.; Fusch, G.; Weitmann, K.; Hoffmann, W.; Fusch, C.; Janz, S.; et al. Prevalence and frequency of circulating $\mathrm{t}(14 ; 18)-\mathrm{MBR}$ translocation carrying cells in healthy individuals. Int. J. Cancer 2009, 124, 958-963. [CrossRef]

16. Hirt, C.; Schüler, F.; Dölken, L.; Schmidt, C.A.; Dölken, G. Low prevalence of circulating t(11;14)(q13;q32)-positive cells in the peripheral blood of healthy individuals as detected by real-time quantitative PCR. Blood 2004, 104, 904-905. [CrossRef]

17. Machiela Mitchell, J.; Zhou, W.; Sampson Joshua, N.; Dean Michael, C.; Jacobs Kevin, B.; Black, A.; Chang, I.-S.; Chen, C.; Chen, C.; Chen, K.; et al. Characterization of Large Structural Genetic Mosaicism in Human Autosomes. Am. J. Hum. Genet. 2015, 96, 487-497. [CrossRef]

18. Roulland, S.; Kelly, R.S.; Morgado, E.; Sungalee, S.; Solal-Celigny, P.; Colombat, P.; Jouve, N.; Palli, D.; Pala, V.; Tumino, R.; et al. $\mathrm{t}(14 ; 18)$ Translocation: A Predictive Blood Biomarker for Follicular Lymphoma. J. Clin. Oncol. 2014, 32, 1347-1355. [CrossRef]

19. Jurinovic, V.; Passerini, V.; Oestergaard, M.Z.; Knapp, A.; Mundt, K.; Araf, S.; Richter, J.; FitzGibbon, J.; Klapper, W.; Marcus, R.E.; et al. Evaluation of the m7-FLIPI in Patients with Follicular Lymphoma Treated within the Gallium Trial: EZH2 mutation Status May be a Predictive Marker for Differential Efficacy of Chemotherapy. Blood 2019, 134 (Suppl. 1), 122. [CrossRef]

20. Jurinovic, V.; Kridel, R.; Staiger, A.M.; Szczepanowski, M.; Horn, H.; Dreyling, M.H.; Rosenwald, A.; Ott, G.; Klapper, W.; Zelenetz, A.D.; et al. Clinicogenetic risk models predict early progression of follicular lymphoma after first-line immunochemotherapy. Blood 2016, 128, 1112-1120. [CrossRef]

21. Lockmer, S.; Ren, W.; Brodtkorb, M.; Østenstad, B.; Wahlin, B.E.; Pan-Hammarström, Q.; Kimby, E. M7-FLIPI is not prognostic in follicular lymphoma patients with first-line rituximab chemo-free therapy. Br. J. Haematol. 2020, 188, 259-267. [CrossRef] [PubMed]

22. Huet, S.; Xerri, L.; Tesson, B.; Mareschal, S.; Taix, S.; Mescam-Mancini, L.; Sohier, E.; Carrère, C.; Lazarovici, J.; Casasnovas, R.-O.; et al. EZH2 alterations in follicular lymphoma: Biological and clinical correlations. Blood Cancer J. 2017, 7, e555. [CrossRef] [PubMed]

23. Zhou, X.A.; Yang, J.; Ringbloom, K.G.; Martinez-Escala, M.E.; Stevenson, K.E.; Wenzel, A.T.; Fantini, D.; Martin, H.K.; Moy, A.P.; Morgan, E.A.; et al. Genomic landscape of cutaneous follicular lymphomas reveals 2 subgroups with clinically predictive molecular features. Blood Adv. 2021, 5, 649-661. [CrossRef]

24. Xian, R.R.; Xie, Y.; Haley, L.M.; Yonescu, R.; Pallavajjala, A.; Pittaluga, S.; Jaffe, E.S.; Duffield, A.S.; McCall, C.M.; Gheith, S.M.F.; et al. CREBBP and STAT6 co-mutation and 16p13 and 1p36 loss define the $t(14 ; 18)$-negative diffuse variant of follicular lymphoma. Blood Cancer J. 2020, 10, 69. [CrossRef] [PubMed]

25. Aronica, M.A.; Goenka, S.; Boothby, M. IL-4-dependent induction of BCL-2 and BCL-X(L)IN activated T lymphocytes through a STAT6- and pi 3-kinase-independent pathway. Cytokine 2000, 12, 578-587. [CrossRef]

26. Ritz, O.; Rommel, K.; Dorsch, K.; Kelsch, E.; Melzner, J.; Buck, M.; Leroy, K.; Papadopoulou, V.; Wagner, S.; Marienfeld, R.; et al. STAT6-mediated BCL6 repression in primary mediastinal B-cell lymphoma (PMBL). Oncotarget 2013, 4, 1093-1102. [CrossRef]

27. Schmidt, J.; Gong, S.; Marafioti, T.; Mankel, B.; Gonzalez-Farre, B.; Balagué, O.; Mozos, A.; Cabeçadas, J.; van der Walt, J.; Hoehn, D.; et al. Genome-wide analysis of pediatric-type follicular lymphoma reveals low genetic complexity and recurrent alterations of TNFRSF14 gene. Blood 2016, 128, 1101-1111. [CrossRef]

28. Rosenwald, A.; Wright, G.; Chan, W.C.; Connors, J.M.; Campo, E.; Fisher, R.I.; Gascoyne, R.D.; Muller-Hermelink, H.K.; Smeland, E.B.; Giltnane, J.M.; et al. The use of molecular profiling to predict survival after chemotherapy for diffuse large-B-cell lymphoma. N. Engl. J. Med. 2002, 346, 1937-1947. [CrossRef]

29. Chalmers, Z.R.; Connelly, C.F.; Fabrizio, D.; Gay, L.; Ali, S.M.; Ennis, R.; Schrock, A.; Campbell, B.; Shlien, A.; Chmielecki, J.; et al. Analysis of 100,000 human cancer genomes reveals the landscape of tumor mutational burden. Genome Med. 2017, 9, 34. [CrossRef]

30. Alizadeh, A.A.; Eisen, M.B.; Davis, R.E.; Ma, C.; Lossos, I.S.; Rosenwald, A.; Boldrick, J.C.; Sabet, H.; Tran, T.; Yu, X.; et al. Distinct types of diffuse large B-cell lymphoma identified by gene expression profiling. Nature 2000, 403, 503-511. [CrossRef]

31. Hans, C.P.; Weisenburger, D.D.; Greiner, T.C.; Gascoyne, R.D.; Delabie, J.; Ott, G.; Müller-Hermelink, H.K.; Campo, E.; Braziel, R.M.; Jaffe, E.S.; et al. Confirmation of the molecular classification of diffuse large B-cell lymphoma by immunohistochemistry using a tissue microarray. Blood 2004, 103, 275-282. [CrossRef]

32. Choi, W.W.L.; Weisenburger, D.D.; Greiner, T.C.; Piris, M.A.; Banham, A.H.; Delabie, J.; Braziel, R.M.; Geng, H.; Iqbal, J.; Lenz, G.; et al. A New Immunostain Algorithm Classifies Diffuse Large B-Cell Lymphoma into Molecular Subtypes with High Accuracy. Clin. Cancer Res. 2009, 15, 5494. [CrossRef]

33. Zhou, Z.; Gao, J.; Popovic, R.; Wolniak, K.; Parimi, V.; Winter, J.N.; Licht, J.D.; Chen, Y.-H. Strong expression of EZH2 and accumulation of trimethylated H3K27 in diffuse large B-cell lymphoma independent of cell of origin and EZH2 codon 641 mutation. Leuk. Lymphoma 2015, 56, 2895-2901. [CrossRef] 
34. Chambwe, N.; Kormaksson, M.; Geng, H.; De, S.; Michor, F.; Johnson, N.A.; Morin, R.; Scott, D.W.; Godley, L.A.; Gascoyne, R.D.; et al. Variability in DNA methylation defines novel epigenetic subgroups of DLBCL associated with different clinical outcomes. Blood 2014, 123, 1699-1708. [CrossRef]

35. Morin, R.D.; Mendez-Lago, M.; Mungall, A.J.; Goya, R.; Mungall, K.L.; Corbett, R.D.; Johnson, N.A.; Severson, T.M.; Chiu, R.; Field, M.; et al. Frequent mutation of histone-modifying genes in non-Hodgkin lymphoma. Nature 2011, 476, 298-303. [CrossRef]

36. Schmitz, R.; Wright, G.W.; Huang, D.W.; Johnson, C.A.; Phelan, J.D.; Wang, J.Q.; Roulland, S.; Kasbekar, M.; Young, R.M.; Shaffer, A.L.; et al. Genetics and Pathogenesis of Diffuse Large B-Cell Lymphoma. N. Engl. J. Med. 2018, 378, $1396-1407$. [CrossRef]

37. Shimada, K.; Yoshida, K.; Suzuki, Y.; Iriyama, C.; Inoue, Y.; Sanada, M.; Kataoka, K.; Yuge, M.; Takagi, Y.; Kusumoto, S.; et al. Frequent genetic alterations in immune checkpoint-related genes in intravascular large B-cell lymphoma. Blood 2021, 137, 1491-1502. [CrossRef]

38. Yoshida, K.; Nakamoto-Matsubara, R.; Chiba, K.; Okuno, Y.; Kakiuchi, N.; Shiraishi, Y.; Sato, Y.; Suzuki, H.; Yoshizato, T.; Shiozawa, Y.; et al. Genetic Basis of Primary Central Nervous System Lymphoma. Blood 2015, 126, 2687. [CrossRef]

39. Rosikiewicz, W.; Chen, X.; Dominguez, P.M.; Ghamlouch, H.; Aoufouchi, S.; Bernard, O.A.; Melnick, A.; Li, S. TET2 deficiency reprograms the germinal center B cell epigenome and silences genes linked to lymphomagenesis. Sci. Adv. 2020, 6, eaay5872. [CrossRef]

40. Fazila, A.; Vasu, P.; Jesper, C.; Marianne, T.P.; Anja, P.; Anders, B.N.; Hother, C.; Ralfkiaer, U.; Brown, P.; Ralfkiaer, E.; et al. Genome-wide profiling identifies a DNA methylation signature that associates with TET2 mutations in diffuse large B-cell lymphoma. Haematologica 2013, 98, 1912-1920.

41. Chapuy, B.; Stewart, C.; Dunford, A.J.; Kim, J.; Kamburov, A.; Redd, R.A.; Lawrence, M.S.; Roemer, M.G.M.; Li, A.J.; Ziepert, M.; et al. Molecular subtypes of diffuse large B cell lymphoma are associated with distinct pathogenic mechanisms and outcomes. Nat. Med. 2018, 24, 679-690. [CrossRef] [PubMed]

42. Wright, G.W.; Huang, D.W.; Phelan, J.D.; Coulibaly, Z.A.; Roulland, S.; Young, R.M.; Wang, J.Q.; Schmitz, R.; Morin, R.; Tang, J.; et al. A Probabilistic Classification Tool for Genetic Subtypes of Diffuse Large B Cell Lymphoma with Therapeutic Implications. Cancer Cell 2020, 37, 551-568.e14. [CrossRef] [PubMed]

43. Szablewski, V.; Bret, C.; Kassambara, A.; Devin, J.; Cartron, G.; Costes-Martineau, V.; Moreaux, J. An epigenetic regulator-related score (EpiScore) predicts survival in patients with diffuse large B cell lymphoma and identifies patients who may benefit from epigenetic therapy. Oncotarget 2018, 9, 19079. [CrossRef] [PubMed]

44. Sha, C.; Barrans, S.; Cucco, F.; Bentley, M.A.; Care, M.A.; Cummin, T.; Kennedy, H.; Thompson, J.S.; Uddin, R.; Worrillow, L.; et al. Molecular High-Grade B-Cell Lymphoma: Defining a Poor-Risk Group That Requires Different Approaches to Therapy. J. Clin. Oncol. 2019, 37, 202-212. [CrossRef]

45. Evrard, S.M.; Péricart, S.; Grand, D.; Amara, N.; Escudié, F.; Gilhodes, J.; Bories, P.; Traverse-Glehen, A.; Dubois, R.; Brousset, P.; et al Targeted next generation sequencing reveals high mutation frequency of CREBBP, BCL2 and KMT2D in high-grade B-cell lymphoma with MYC and BCL2 and/or BCL6 rearrangements. Haematologica 2019, 104, e154-e157. [CrossRef]

46. Queiros, A.; Beekman, R.; Vilarrasa-Blasi, R.; Duran-Ferrer, M.; Clot, G.; Merkel, A.; Raineri, E.; Russiñol, N.; Castellano, G.; Beà, S.; et al. Decoding the DNA Methylome of Mantle Cell Lymphoma in the Light of the Entire B Cell Lineage. Cancer Cell 2016, 30, 806-821. [CrossRef]

47. Enjuanes, A.; Albero, R.; Clot, G.; Navarro, A.; Bea, S.; Pinyol, M.; Martin-Subero, J.I.; Klapper, W.; Staudt, L.M.; Jaffe, E.S.; et al. Genome-wide methylation analyses identify a subset of mantle cell lymphoma with a high number of methylated CpGs and aggressive clinicopathological features. Int. J. Cancer 2013, 133, 2852-2863. [CrossRef]

48. Nadeu, F.; Martin-Garcia, D.; Clot, G.; Díaz-Navarro, A.; Duran-Ferrer, M.; Navarro, A.; Vilarrasa-Blasi, R.; Kulis, M.; Royo, R.; Gutiérrez-Abril, J.; et al. Genomic and epigenomic insights into the origin, pathogenesis, and clinical behavior of mantle cell lymphoma subtypes. Blood 2020, 136, 1419-1432. [CrossRef]

49. Simone, F.; Davide, R.; Andrea, R.; Alessio, B.; Valeria, S.; Christian, W.E.; Evangelista, A.; Moia, R.; Kwee, I.; Dahl, C.; et al. KMT2D mutations and TP53 disruptions are poor prognostic biomarkers in mantle cell lymphoma receiving high-dose therapy: A FIL study. Haematologica 2020, 105, 1604-1612.

50. Zhang, J.; Jima, D.; Moffitt, A.; Liu, Q.; Czader, M.; Hsi, E.D.; Fedoriw, Y.; Dunphy, C.H.; Richards, K.L.; Gill, J.I.; et al. The genomic landscape of mantle cell lymphoma is related to the epigenetically determined chromatin state of normal B cells. Blood 2014, 123, 2988-2996. [CrossRef]

51. Jeong, S.; Park, Y.J.; Yun, W.; Lee, S.-T.; Choi, J.R.; Suh, C.; Jo, J.-C.; Cha, H.J.; Jeong, J.-Y.; Chang, H.; et al. Genetic heterogeneity and prognostic impact of recurrent ANK2 and TP53 mutations in mantle cell lymphoma: A multi-centre cohort study. Sci. Rep. 2020, 10, 13359. [CrossRef]

52. Martinez-Baquero, D.; Sakhdari, A.; Mo, H.; Kim, D.H.; Kanagal-Shamanna, R.; Li, S.; Young, K.H.; O’Malley, D.P.; Dogan, A.; Jain, P.; et al. EZH2 expression is associated with inferior overall survival in mantle cell lymphoma. Mod. Pathol. 2021, 34, 2183-2191. [CrossRef]

53. Kulis, M.; Heath, S.; Bibikova, M.; Queirós, A.C.; Navarro, A.; Clot, G.; Martínez-Trillos, A.; Castellano, G.; Brun-Heath, I.; Pinyol, M.; et al. Epigenomic analysis detects widespread gene-body DNA hypomethylation in chronic lymphocytic leukemia. Nat. Genet. 2012, 44, 1236-1242. [CrossRef] 
54. Queiros, A.; Villamor, N.; Clot, G.; Martineztrillos, A.; Kulis, M.; Navarro, A.; Penas, E.M.M.; Jayne, S.; Majid, A.M.S.A.; Richter, J.A.; et al. A B-cell epigenetic signature defines three biologic subgroups of chronic lymphocytic leukemia with clinical impact. Leukemia 2015, 29, 598-605. [CrossRef]

55. Tsagiopoulou, M.; Papakonstantinou, N.; Moysiadis, T.; Mansouri, L.; Ljungström, V.; Duran-Ferrer, M.; Malousi, A.; Queirós, A.C.; Plevova, K.; Bhoi, S.; et al. DNA methylation profiles in chronic lymphocytic leukemia patients treated with chemoimmunotherapy. Clin. Epigenetics 2019, 11, 177. [CrossRef]

56. Rodríguez, D.; Bretones, G.; Quesada, V.; Villamor, N.; Arango, J.R.; López-Guillermo, A.; Ramsay, A.J.; Baumann, T.; Quiros, P.M.; Navarro, A.; et al. Mutations in CHD2 cause defective association with active chromatin in chronic lymphocytic leukemia. Blood 2015, 126, 195-202. [CrossRef]

57. Pillonel, V.; Juskevicius, D.; Ng, C.K.Y.; Bodmer, A.; Zettl, A.; Jucker, D.; Dirnhofer, S.; Tzankov, A. High-throughput sequencing of nodal marginal zone lymphomas identifies recurrent BRAF mutations. Leukemia 2018, 32, 2412-2426. [CrossRef]

58. Jung, H.; Yoo, H.Y.; Lee, S.H.; Shin, S.; Kim, S.C.; Lee, S.; Ko, Y.H. The mutational landscape of ocular marginal zone lymphoma identifies frequent alterations in TNFAIP3 followed by mutations in TBL1XR1 and CREBBP. Oncotarget 2017, 8, 17038-17049. [CrossRef]

59. Parry, M.; Rose-Zerilli, M.; Ljungström, V.; Gibson, J.; Wang, J.; Walewska, R.; Parker, H.; Parker, A.; Davis, Z.; Gardiner, A.; et al Genetics and Prognostication in Splenic Marginal Zone Lymphoma: Revelations from Deep Sequencing. Clin. Cancer Res. Off. J. Am. Assoc. Cancer Res. 2015, 21, 4174-4183. [CrossRef]

60. Arribas, A.J.; Rinaldi, A.; Mensah, A.A.; Kwee, I.; Cascione, L.; Robles, E.F.; Martinez-Climent, J.A.; Oscier, D.; Arcaini, L.; Baldini, L.; et al. DNA methylation profiling identifies two splenic marginal zone lymphoma subgroups with different clinical and genetic features. Blood 2015, 125, 1922-1931. [CrossRef]

61. Ushmorov, A.; Leithäuser, F.; Sakk, O.; Weinhaüsel, A.; Popov, S.W.; Möller, P.; Wirth, T. Epigenetic processes play a major role in B-cell-specific gene silencing in classical Hodgkin lymphoma. Blood 2006, 107, 2493-2500. [CrossRef]

62. Roemer, M.G.M.; Ligon, A.H.; Engert, A.; Younes, A.; Santoro, A.; Zinzani, P.L.; Timmerman, J.M.; Ansell, S.; Armand, P.; Fanale, M.A.; et al. Chromosome 9p24.1/PD-L1/PD-L2Alterations and PD-L1 Expression and Treatment Outcomes in Patients with Classical Hodgkin Lymphoma Treated with Nivolumab (PD-1 Blockade). Blood 2016, 128, 2923. [CrossRef]

63. Mata, E.; Díaz-López, A.; Martín-Moreno, A.M.; Sánchez-Beato, M.; Varela, I.; Mestre, M.J.; Santonja, C.; Burgos, F.; Menárguez, J.; Estévez, M.; et al. Analysis of the mutational landscape of classic Hodgkin lymphoma identifies disease heterogeneity and potential therapeutic targets. Oncotarget 2017, 8, 111386. [CrossRef]

64. Swerdlow, S.H.; Campo, E.; Pileri, S.A.; Harris, N.L.; Stein, H.; Siebert, R.; Advani, R.; Ghielmini, M.; Salles, G.A.; Zelenetz, A.D.; et al. The 2016 revision of the World Health Organization classification of lymphoid neoplasms. Blood 2016, 127, 2375-2390. [CrossRef]

65. Lemonnier, F.; Couronné, L.; Parrens, M.; Jaïs, J.P.; Travert, M.; Lamant, L.; Tournillac, O.; Rousset, T.; Fabiani, B.; Cairns, R.A.; et al. Recurrent TET2 mutations in peripheral T-cell lymphomas correlate with TFH-like features and adverse clinical parameters. Blood 2012, 120, 1466-1469. [CrossRef]

66. Watatani, Y.; Sato, Y.; Miyoshi, H.; Sakamoto, K.; Nishida, K.; Gion, Y.; Nagata, Y.; Shiraishi, Y.; Chiba, K.; Tanaka, H.; et al. Molecular heterogeneity in peripheral T-cell lymphoma, not otherwise specified revealed by comprehensive genetic profiling. Leukemia 2019, 33, 2867-2883. [CrossRef]

67. Ghione, P.; Faruque, P.; Mehta-Shah, N.; Seshan, V.; Ozkaya, N.; Bhaskar, S.; Yeung, J.; Spinner, M.A.; Lunning, M.; Inghirami, G.; et al. $\mathrm{T}$ follicular helper phenotype predicts response to histone deacetylase inhibitors in relapsed/refractory peripheral T-cell lymphoma. Blood Adv. 2020, 4, 4640-4647. [CrossRef]

68. Odejide, O.; Weigert, O.; Lane, A.A.; Toscano, D.; Lunning, M.A.; Kopp, N.; Kim, S.S.; Van Bodegom, D.; Bolla, S.; Schatz, J.; et al. A targeted mutational landscape of angioimmunoblastic T-cell lymphoma. Blood 2014, 123, 1293-1296. [CrossRef]

69. Cairns, R.A.; Iqbal, J.; Lemonnier, F.; Kucuk, C.; de Leval, L.; Jais, J.-P.; Parrens, M.; Martin, A.; Xerri, L.; Brousset, P.; et al. IDH2 mutations are frequent in angioimmunoblastic T-cell lymphoma. Blood 2012, 119, 1901-1903. [CrossRef]

70. Figueroa, M.E.; Abdel-Wahab, O.; Lu, C.; Ward, P.S.; Patel, J.; Shih, A.; Li, Y.; Bhagwat, N.; VasanthaKumar, A.; Fernandez, H.F.; et al. Leukemic IDH1 and IDH2 mutations result in a hypermethylation phenotype, disrupt TET2 function, and impair hematopoietic differentiation. Cancer Cell 2010, 18, 553-567. [CrossRef]

71. Nguyen, P.N.; Tran, N.T.B.; Nguyen, T.P.X.; Ngo, T.N.M.; Lai, D.V.; Deel, C.D.; Hassellf, L.A.; Vuong, H.G. Clinicopathological Implications of RHOA Mutations in Angioimmunoblastic T-Cell Lymphoma: A Meta-analysis: RHOA mutations in AITL. Clin. Lymphoma Myeloma Leuk. 2021, 21, 431-438. [CrossRef] [PubMed]

72. Wang, C.; McKeithan, T.W.; Gong, Q.; Zhang, W.; Bouska, A.; Rosenwald, A.; Gascoyne, R.D.; Wu, X.; Wang, J.; Muhammad, Z.; et al. IDH2R172 mutations define a unique subgroup of patients with angioimmunoblastic T-cell lymphoma. Blood 2015, 126, 1741-1752. [CrossRef] [PubMed]

73. Zhang, P.; Zhang, M. Epigenetic alterations and advancement of treatment in peripheral T-cell lymphoma. Clin. Epigenetics 2020, 12, 169. [CrossRef]

74. Weinstein, J.N.; Collisson, E.A.; Mills, G.B.; Shaw, K.R.; Ozenberger, B.A.; Ellrott, K.; Shmulevich, I.; Sander, C.; Stuart, J.M. The Cancer Genome Atlas Pan-Cancer analysis project. Nat. Genet. 2013, 45, 1113-1120. [CrossRef] [PubMed] 
75. Kiel, M.J.; Sahasrabuddhe, A.A.; Rolland, D.C.M.; Velusamy, T.; Chung, F.; Schaller, M.; Bailey, N.G.; Betz, B.L.; Miranda, R.N.; Porcu, P.; et al. Genomic analyses reveal recurrent mutations in epigenetic modifiers and the JAK-STAT pathway in Sézary syndrome. Nat. Commun. 2015, 6, 8470. [CrossRef] [PubMed]

76. Choi, J.; Goh, G.; Walradt, T.; Hong, B.S.; Bunick, C.G.; Chen, K.; Bjornson, R.D.; Maman, Y.; Wang, T.; Tordoff, J.; et al. Genomic landscape of cutaneous T cell lymphoma. Nat. Genet. 2015, 47, 1011-1019. [CrossRef] [PubMed]

77. van Doorn, R.; Slieker, R.C.; Boonk, S.E.; Zoutman, W.H.; Goeman, J.J.; Bagot, M.; Michel, L.; Tensen, C.P.; Willemze, R.; Heijmans, B.T.; et al. Epigenomic Analysis of Sézary Syndrome Defines Patterns of Aberrant DNA Methylation and Identifies Diagnostic Markers. J. Investig. Dermatol. 2016, 136, 1876-1884. [CrossRef]

78. Michel, L.; Jean-Louis, F.; Begue, E.; Bensussan, A.; Bagot, M. Use of PLS3, Twist, CD158k/KIR3DL2, and NKp46 gene expression combination for reliable Sézary syndrome diagnosis. Blood 2013, 121, 1477-1478. [CrossRef] 